\title{
AKTIVITAS ANTIPIRETIK EKSTRAK ETANOL KULIT BUAH RAMBUTAN (Nephelium lappaceum L) SECARA IN VIVO DAN KANDUNGAN FENOLIK TOTALNYA
}

\author{
I Made Dira Swantara*, Riski Fatur Rachman dan Ni Made Puspawati
}

Progam Studi Kimia FMIPA Universitas Udayana, Bukit Jimbaran, Badung, Bali 80361

*Email:m_dira_swantara@yahoo.co.id

\begin{abstract}
ABSTRAK
Penelitian ini bertujuan untuk mengetahui efek antipiretik ekstrak etanol kulit buah rambutan dan menentukan kandungan fenolik totalnya. Metode untuk uji aktivitas antipiretik dilakukan secara invivo menggunakan ragi tape untuk menginduksi demam pada tikus jantan galur Wistar dan menggunakan metode Folin-Coicalteu untuk mengukur total fenolnya. Hasil skrining fitokimia menunjukkan adanya senyawa golongan fenolik, tanin, flavonoid, saponin, dan terpenoid, dengan kandungan senyawa fenoliknya yang lebih dominan. Hasil penelitian menunjukkan pemberian ekstrak etanol kulit buah rambutan pada dosis $5 ; 10$ dan 20 $\mathrm{mg} / 100 \mathrm{~g}$ BB bersifat antipiretik dengan terjadinya penurunan suhu rectal tikus dibandingkan dengan kontrol negatif dan penurunan suhu yang tajam terlihat pada menit ke-210 setelah pemberian ekstrak. Kandungan fenol total dalam ekstrak etanol kulit buah rambutan yang diperoleh sebesar 39,7861 g GAE/100 g atau 39,78\%.
\end{abstract}

Kata kunci: antipiretik, kulit buah rambutan, Nephelium lappaceum, total fenolik

\begin{abstract}
This study aimed to determine the antipyretic effect of ethanol extract of Nephelium lappaceum fruit peel and to determine its total phenol content. In vivo antipyretic activity test was conducted on Wistar male rats induced with yeast and applying Folin-Coicalteu method for determining the total phenol content of the extract. The tests result showed an antipyretic activity with the application of the extracts at the doses of $5 \mathrm{mg} / 100 \mathrm{~g}$ $\mathrm{BW} ; 10 \mathrm{mg} / 100 \mathrm{~g} \mathrm{BW}$, and $20 \mathrm{mg} / 100 \mathrm{~g} \mathrm{BW}$ indicated by a reduction of rectal temperature of the rats compared to the negative control and the sharp reducing temperature was observed after 210 minutes of oral administration of the extract. Phytochemical screening results indicated the presence of phenol, tannin, flavonoid, saponin and terpenoid, with phenolic compound predominantly. The total phenol content of ethanol extract of Nephelium lappaceum fruit peel was $39.7861 \mathrm{~g} \mathrm{GAE} / 100 \mathrm{~g}$ or $39.78 \%$.
\end{abstract}

Keywords: antipyretic Nephelium lappaceum fruit peel, total phenolic

\section{PENDAHULUAN}

Pireksia atau demam merupakan gejala meningkatnya suhu tubuh diatas $37,2^{\circ} \mathrm{C}$ yang disebabkan oleh kelainan di dalam otak atau suatu infeksi oleh bahan-bahan toksik berupa bakteri, virus dan mikroba tertentu (Guyton dan Hall, 1997). Demam dapat diatasi dengan obat antipiretik atau obat penurun suhu tubuh (Gunawan et al., 2007).

Negara kepulauan dengan wilayah yang luas seperti Indonesia khususnya untuk daerah terpencil sering menghadapi masalah dalam mengakses kesehatan sehingga secara tradisional menggunakan bahan alam untuk pengobatan. (Zainol et. al., 2014). Salah satu tumbuhan yang sering dimanfaatkan untuk pengobatan yaitu rambutan (Nephelium lappaceum L). Kulit buah rambutan secara empiris telah dimanfaatkan oleh masyarakat Indonesia di berbagai daerah sebagai obat penurun demam atau antipiretik (Dalimartha, 2008). Namun kajian ilmiah tentang efek antipiretik dari kulit buah rambutan belum banyak dipublikasikan. Tjandra et al. (2011) melaporkan kulit buah rambutan rapiah mengandungan senyawa steroid, terpenoid, fenolik, dan flavonoid dengan kandungan senyawa fenolik yang dominan dan menunjukkan aktivitas antioksidan yang lebih tinggi dibandingkan dengan asam askorbat. Kandungan fenolik yang tinggi pada kulit buah rambutan rapiah berpotensi untuk dimanfaatkan sebagai obat penurun panas 
karena kemiripan stukturnya dengan senyawa penurun panas sintetik parasetamol yang mengandung gugus fenolik. Berdasarkan latar belakang diatas, maka penelitian ini dilakukan untuk menguji aktivitas antipiretik dan menentukan kandungan fenolik total ekstrak etanol kulit buah rambutan. Salah satu metode uji aktivitas antipiretik adalah uji secara in vivo menggunakan tikus jantan galur wistar yang diinduksi ragi (Sini et al., 2011). Induksi demam dengan ragi dipilih karena lebih efisien, mudah didapat dan digunakan dibandingkan dengan penginduksi demam lainnya. Analisis kandungan fenolik total dilakukan secara spektrofotometri menggunakan pereaksi Folin-Coicalteu.

\section{MATERI DAN METODE}

\section{Bahan}

Objek uji yang digunakan dalam penelitian ini adalah kulit buah rambutan (Nephelium lappaceum L) yang berwarna kuning kemerahan hingga merah sebanyak 4 kg yang dikumpulkan dari wilayah Kintamani, Bangli, Bali pada bulan Januari 2016. Subjek uji dalam penelitian ini adalah tikus jantan galur Wistar (Rattus Norvegicus L.) sebanyak 25 ekor berumur \pm 8 minggu dengan berat rata-rata $100-120 \mathrm{~g}$.

Bahan kimia yang digunakan meliputi aquades, etanol $70 \%$, etanol $95 \%, \mathrm{FeCl}_{3}$, $\mathrm{H}_{2} \mathrm{SO}_{4}$ pekat, pereaksi Mayer, pereaksi Wagner, asetat anhidrat, serbuk $\mathrm{Mg}, \mathrm{HCl}$ pekat, $\mathrm{HCl}$ encer, amonia, kloroform p.a., metanol p.a., $\mathrm{Na}_{2} \mathrm{CO}_{3} 20 \%$ (b/v), pereaksi Folin-Coicalteu, asam galat, parasetamol dan suspensi ragi tapemerek $\mathrm{Na}$ KokLiong 20\% (b/v).

\section{Peralatan}

Alat yang digunakan dalam penelitian ini adalah kaca arloji, gelas ukur, botol vial, pipet tetes, pengaduk, erlenmeyer, gelas beker, tabung reaksi, labu ukur,pipet volume, blender, alat maserasi, rotary evaporator, termometer digital, jarum suntik, sonde, slop tangan, neraca analitik, kapas, kertas saring, sendok, aluminium foil, masker dan Spektrofotometer UV-VisShimadzu/UV-1800.

\section{CARA KERJA}

\section{Preparasi, ekstraksi dan skrining fitokimia}

Sampel kulit buah rambutan segar dibersihkan dan dikeringanginkan selama 48 jam. Sampel yang telah kering selanjutnya diblender sehingga diperoleh serbuk, selanjutnya ditimbang, dan ditentukan kadar airnya. Sampel kemudian diekstraksi pada suhu kamar dengan etanol $70 \%$ selama $(2 \mathrm{x}$ 24) jam. Ekstrak yang diperoleh selanjutnya dievaporasi sehinggadidapatkan ekstrak kental. Ekstrak ini kemudian diskrining kandungan metabolit sekundernya yang meliputi uji fenolik, tanin, flavonoid, saponin, terpenoid, steroid, dan alkaloid.

\section{Analisis kandungan fenol total}

Analisis kandungan total fenol dilakukan secara spektrofotometri dengan metode Folin-Coicalteu. Sampel sebanyak 0,5 gram dilarutkan dalam metanol sampai volumenya $100 \mathrm{~mL}$, kemudian $1 \mathrm{~mL}$ larutan tersebut diambil dan diencerkan dengan aquades sampai volumenya $100 \mathrm{~mL}$. Sebanyak 0,5 $\mathrm{mL}$ larutan sampel tersebut kemudian ditambahkan dengan 0,5 mL pereaksi FolinCoicalteu, didiamkan selama 3 menit, $\begin{array}{llllll}\text { ditambahkan } & 1,5 & \mathrm{~mL} & \mathrm{Na}_{2} \mathrm{CO}_{3} & 20 \% & (\mathrm{~b} / \mathrm{v})\end{array}$ kemudian didiamkan pada suhu kamar selama 1 jam. Sampel selanjutnya dianalisis dengan Spektrofotometer UV-Vis pada panjang gelombang $765 \mathrm{~nm}$ sebanyak tiga kali ulangan. Standar yang digunakan adalah standar asam galat dengan konsentrasi 5 ppm; 10 ppm; 20 ppm; 40 ppm, dan 80 ppm.

\section{Uji antipiretik}

Metode uji antipiretik dilakukan secara in vivo menggunakan tikus jantan galur Wistar. Untuk mengindukasi demam pada tikus digunakan suspensi ragi tape dengan cara menginjeksikan secara intramuskular. Sebanyak 25 ekor tikus dengan berat rata-rata 100-120 gram diadaptasikan terlebih dahulu selama 1 minggu kemudian dikelompokan secara acak menjadi 5 kelompok sehingga terdapat 5 ekor tikus pada masing-masing kelompok. Suhu rectal tikus pada masingmasing kelompok diukur sebelum dan 3 jam setelah injeksi suspensi ragi tape $20 \%$ (b/v) sebanyak $1 \mathrm{~mL}$. Setelah 4 jam diinjeksi ragi, masing-masing kelompok tikus diberikan perlakuan yaitu kelompok 1(kontrol negatif) diberikan aquades, kelompok 2(kontrol positif) diberikan parasetamol dosis $6,3 \mathrm{mg} / 100 \mathrm{~g} \mathrm{BB}$, kelompok 3 diberikan ekstrak sampel dosis 5 mg/100 g BB, kelompok 4 diberikan ekstrak sampel dosis $10 \mathrm{mg} / 100 \mathrm{~g} \mathrm{BB}$, dan kelompok 5 diberikan ekstrak sampel dosis $20 \mathrm{mg} / 100 \mathrm{~g}$ 
BB. Kemudian suhu rectal tikus diukur setiap 30 menit selama 4 jam dan hasil pengukuran yang diperoleh kemudian dianalsis menggunakan software statistika SPSS 22 metode ANOVA dan Tukey/HSD.

\section{HASIL DAN PEMBAHASAN}

\section{Preparasi, ekstraksidan skrining fitokimia sampel}

Dari 1,6 kg kulit buah rambutan segar setelah dikeringanginkan selama 48 jam dan diblender,diperoleh $604 \mathrm{~g}$ serbuk kulit buah rambutan kering dengan kadar air 9,4\%. Maserasi serbuk kulit buah rambutan dengan etanol $70 \%$ didapatkan 45 g ekstrak kental etanol. Hasil skrining fitokimia menunjukan ekstrak etanol tersebut positif mengandung senyawa golongan fenolik, flavonoid, tannin, saponin, dan terpenoid dengan kandungan senyawa fenoliknya yang lebih dominan dilihat dari intensitas perubahan warna yang dihasilkan.Oleh karena itu, maka dilakukan analisis kandungan fenolik total secara spektrofotometri. Hasil uji fitokimia ini sesuai dengan hasil penelitian yang dilaporkan olehTjandra et al. (2011) tentang kandungan senyawa yang dominan pada kulit buah rambutan rapiah yaitu senyawa golonganfenolik.

\section{Analisis kandungan fenol total}

Kandungan total fenol ekstrak etanol kulit buah rambutan ditetapkan secara sepktrofotometri dengan metode FolinCoicalteu dan menggunakan asam galat sebagaistandar. Kurva kalibrasi dibuat dari standar asam galat dengan seri konsentrasi 5$80 \mathrm{ppm}$ yang telah diukur absorbansinya dan memberikan suatu persamaan regresi linier $\mathrm{y}=$ $0,0212 x+0,1662$ dengan $R^{2}=0,9965$. Hasil analisis kandungan total fenol sampel ditunjukan pada Tabel 1 berikut.
Tabel 1. Hasil Pengukuran Fenol Total

\begin{tabular}{|cccc|}
\hline Sampel & Abs. & $\begin{array}{c}\text { Kons. } \\
(\mathrm{mg} / \mathrm{mL})\end{array}$ & $\begin{array}{c}\text { Total fenol } \\
(\mathrm{g} \text { GAE / } \\
100 \mathrm{~g})\end{array}$ \\
\hline 1 & 0,5874 & 19,8679 & 39,73 \\
2 & 0,5882 & 19,9056 & 39,81 \\
3 & 0,5882 & 19,9056 & 39,81 \\
Rerata & & $19,8930 \pm 0$ & 39,78 \\
& &, 0218 & \\
\hline
\end{tabular}

Seperti tertera pada Tabel 1. Kandungan total fenol ekstrak etanol kulit buah rambutan sebesar $39,78 \%$ atau 39,78 g GAE / $100 \mathrm{~g}$.

Asam galat merupakan jenis senyawa golongan fenolik dari asam fenolat dengan struktur $\mathrm{C}_{7}$ sedangkan dalam skrining fitokimia ditemukan hasil positif senyawa flavonoid yang memiliki struktur $\mathrm{C}_{15}$ dan tanin yang memiliki struktur oligomer atau polimer (Harborne \& Simmonds, 1964). Hal tersebut mengindikasikan kemungkinan dari senyawa golongan fenolik lain yang memiliki struktur lebih besar dan kompleks tidak terukur dengan metode yang digunakan.

\section{Uji antipiretik}

Pengujian efek antipiretik diawali dengan pemberian ragi tape $20 \% \quad(\mathrm{~b} / \mathrm{v})$ sebanyak $1 \mathrm{ml} / 100 \mathrm{~g} \mathrm{BB}$ untuk membuat suhu tubuh tikus meningkat karena mikroorganisme dalam ragi akan dianggap benda asing oleh sistem kekebalan tubuh yang akan menyebabkan terjadinya mekanisme demam (Guyton dan Hall, 1997). Hewan uji yang dapat digunakan untuk pengujian aktivitas anti piretik hanya yang menunjukkan kenaikan suhu tubuh rata-rata diatas $0,7^{\circ} \mathrm{C}$ setelah $3 \mathrm{jam}$ induksi demam dengan pemberian ragi (Sini et al., 2011). Pada penelitian yang dilakukan ini, semua hewan uji pada jam ke-3 setelah injeksi ragi tape menunjukkan peningkatan suhu tubuh di atas $0,7{ }^{\circ} \mathrm{C}$. Hasil pengukuran suhu tubuh rata-rata hewan uji setelah diberikan perlakuan ditunjukan pada Tabel 2. 
Tabel 2. Suhu Tubuh Rata-rata Hewan Uji Setelah Diberi Perlakuan

\begin{tabular}{|c|c|c|c|c|c|}
\hline \multirow{2}{*}{$\begin{array}{l}\text { Waktu } \\
\text { (jam) }\end{array}$} & \multicolumn{5}{|c|}{ Suhu tubuh rata-rata hewan uji $\left({ }^{\circ} \mathrm{C}\right)$} \\
\hline & $\begin{array}{l}\text { Kontrol } \\
\text { Negatif }\end{array}$ & Parasetamol & $\begin{array}{c}5 \mathrm{mg} / 100 \mathrm{~g} \\
\mathrm{BB}\end{array}$ & $\begin{array}{c}10 \mathrm{mg} / 100 \mathrm{~g} \\
\mathrm{BB}\end{array}$ & $20 \mathrm{mg} / 100 \mathrm{~g} \mathrm{BB}$ \\
\hline 0 & $37,6 \pm 0,21$ & $37,4 \pm 0,28$ & $37,7 \pm 0,18$ & $37,4 \pm 0,26$ & $37,3 \pm 0,30$ \\
\hline 0,5 & $38,4 \pm 0,46$ & $38,3 \pm 0,40$ & $38,0 \pm 0,26$ & $37,9 \pm 0,37$ & $37,7 \pm 0,35$ \\
\hline 1,0 & $38,6 \pm 0,32$ & $38,0 \pm 0,33$ & $38,1 \pm 0,29$ & $37,5 \pm 0,29$ & $37,3 \pm 0,37$ \\
\hline 1,5 & $38,6 \pm 0,32$ & $37,8 \pm 0,23$ & $38,0 \pm 0,27$ & $38,2 \pm 0,23$ & $37,6 \pm 0,35$ \\
\hline 2,0 & $38,4 \pm 0,37$ & $37,7 \pm 0,20$ & $38,1 \pm 0,10$ & $38,2 \pm 0,15$ & $37,7 \pm 0,20$ \\
\hline 2,5 & $38,6 \pm 0,38$ & $37,9 \pm 0,08$ & $38,1 \pm 0,23$ & $38,2 \pm 0,15$ & $37,8 \pm 0,12$ \\
\hline 3,0 & $38,2 \pm 0,08$ & $38,2 \pm 0,31$ & $38,1 \pm 0,27$ & $37,7 \pm 0,25$ & $37,3 \pm 0,13$ \\
\hline 3,5 & $38,3 \pm 0,22$ & $37,8 \pm 0,37$ & $37,7 \pm 0,32$ & $37,3 \pm 0,24$ & $36,9 \pm 0,54$ \\
\hline 4,0 & $38,5 \pm 0,32$ & $37,4 \pm 0,31$ & $38,0 \pm 0,39$ & $38,0 \pm 0,27$ & $37,5 \pm 0,33$ \\
\hline
\end{tabular}

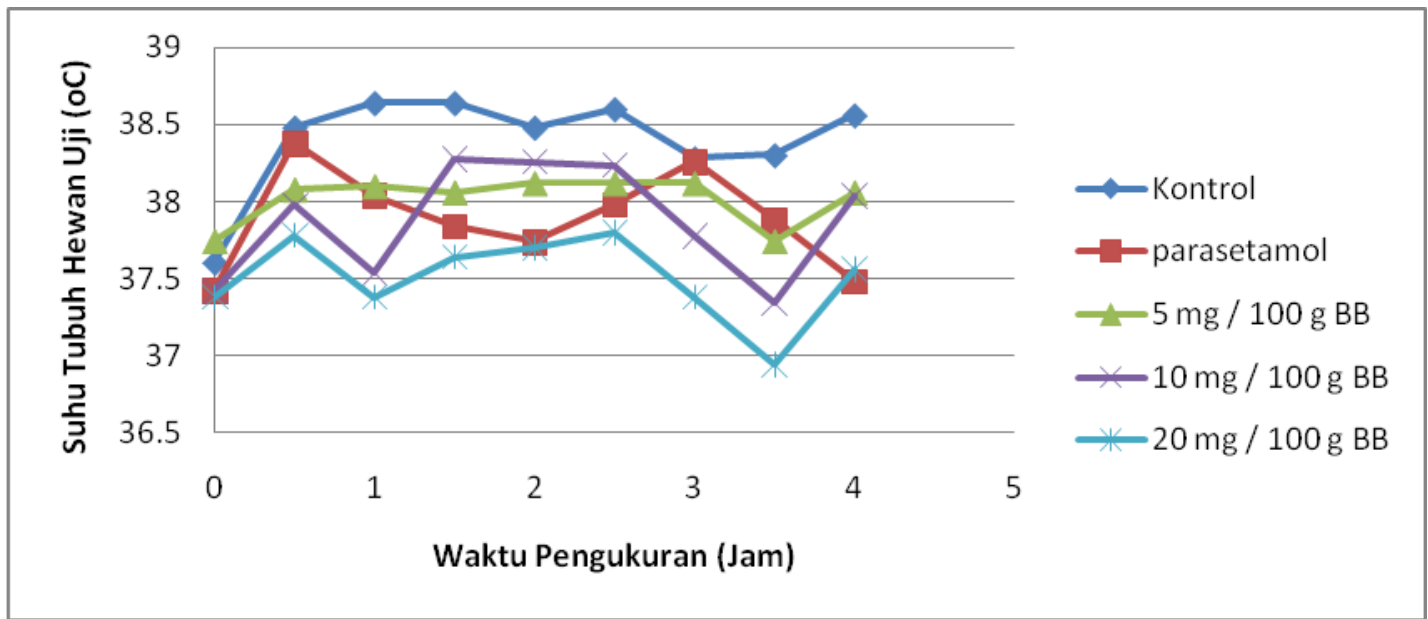

Gambar 1. Grafik suhu tubuh hewan uji setelah diberi perlakuan

Grafik suhu rectal tubuh rata-rata hewan uji pada Gambar 1 menunjukan semua kelompok perlakuan dan control positif menunjukkan suhu rectal tikus dibawah suhu rectal kelompok control negatif. Setelah menitke 30- sampai ke-60 kelompol 2 dan kelompok 3 menunjukkan penurunan suhu rectal yang cukup besar kemudian suhunya meningkat lagi sampai menit ke-150 dan setelah itu menurun dengan tajam. Penurunan suhu yang tajam ditunjukkan oleh kelompok perlakuan 2 dan 3 yaitu setelah menit ke-150 sampai ke-210 dengan penurunan suhu yang lebih besar dari control positif parasetamol. Hal ini mengindikasikan jika ekstrak etanol kulit buah rambutan bekerja dengan effektif untuk dosis 10 dan $20 \mathrm{mg} / 100 \mathrm{~g}$ BB setelah menit ke-150 sampai menit ke-210 dan setelah itu efeknya mulai menurun dibandingkan dengan control positif. Untuk kelompok 1 penurunan suhu rectal tikus baru terjadi pada menit ke-210 dan setelah itu suhu tubuh tikus mengalami peningkatan kembali. Hal ini menunjukkan pemberian ekstrak etanol kulit buah rambutan dosis $5 \mathrm{mg} / 100 \mathrm{~g}$ BB kurang effektif dibandingkan deangan kelompok perlakuan 2 dan 3. Pemberian ekstrak dengan semua dosis setelah menit ke-210 (3,5 jam) mengalami kenaikan suhu tubuh menuju kekeadaan demam kembali. Hal tersebut menandakan aktivitas antipiretik ekstrak hanya bekerja hingga menit ke-210 sedangkan untuk pemberian parasetamol aktivitas antipiretik masih ditunjukkan sampai menit ke-240 (setelah 3,5 jam). Hasil analisis ANOVA menunjukan terdapatnya perbedaan rata-rata antar setiap perlakuan dengan kontrol pada setiap waktu. Hasil tersebut menunjukan ekstrak etanol kulit buah rambutan memiliki aktivitas antipiretik. Hasil Tukey/HSD menunjukan ekstrak dosis $20 \mathrm{mg} / 100 \mathrm{~g}$ BB memiliki penurunan suhu tubuh paling besar dibandingkan perlakuan lainnya.

Hasil skrining fitokimia menunjukan bahwa senyawa yang paling dominan dalam ekstrak etanol kulit buah rambutan adalah senyawa fenolik. Schubert et al. (1999) melaporkan flavonoid (salah satu senyawa 
golongan fenolik) pada minyak biji pomegranat mampu menghambat siklo oksigenase sebesar 31-44 \%, sedangkan You et al. (1999) juga melaporkan derivat dari flavonoid mampu menghambat aktivitas siklo oksigenase. Siklo oksigenase adalah salah satu enzim yang dapat mensintesis terbentuknya prostaglandin. Fenolik yang menghambat kerja siklooksigenase akan menyebabkan prostaglandin tidak akan terbentuk, sehingga membuat suhu tubuh menuju kekeadaan normal. Dengan demikian, kandungan senyawa fenolik pada ekstrak etanol kulit buah rambutan kemungkinan berkontribusi menurunkan suhu tubuh hewan uji atau sebagai obat antipiretik.

\section{SIMPULAN DAN SARAN}

\section{Simpulan}

Ekstrak etanol kulit buah rambutan memiliki aktivitas antipiretik terhadap tikus jantan galur wistar terinduksi ragi pada semua dosis yang diujikan yaitu $5 \mathrm{mg} / 100 \mathrm{~g} \mathrm{BB} ; 10$ $\mathrm{mg} / 100 \mathrm{~g}$ BB; dan 20mg/100 g BB. Kandungan fenol total dalam ekstrak etanol kulit buah rambutan sebesar 39,7861 g GAE/ $100 \mathrm{~g}$ atau $39,78 \%$.

\section{Saran}

Perlu dilakukan pemisahan, pemurnian, dan identifikasi senyawa aktif antipiretik dari ekstrak etanol kulit buah rambutan.

\section{UCAPAN TERIMAKASIH}

Penulis mengucapkan terimakasih kepada semua dosen, staff dan teman-teman di Jurusan Kimia Fakultas Matematika dan Ilmu Pengetahuan Alam Universitas Udayana yang telah membantu dalam bimbingan dan pelaksanaan uji aktivitas antipiretik kulit buah rambutan.

\section{DAFTAR PUSTAKA}

Cindric, I. J., Kunstic, M., Zeiner, M., Stingeder, G., and Rusak, G., 2011, Sampel Preparation Methods for the Determination of the Antioxidative Capacity of Apple Juice, Croat. Chem. Acta, 84 (3): 435-438
Dalimartha, S., 2008, Atlas Tumbuhan Obat Indonesia, Jilid 5, Pustaka Bunda, Jakarta

Gunawan, S.G., Setiabudy, R., Nafrialdi, dan Elysabeth, 2007, Farmakologi dan Terapi, $5^{\text {th }}$ ed., Departemen Farmakologi dan Terapeutik Fakultas Kedokteran, Universitas Indonesia, Jakarta

Guyton, A. C., dan Hall, J. E., 1997, Buku Ajar: Farmakologi Kedokteran, $9^{\text {th }}$ ed., a.b. Setiawan, I., Tengadi K.A., dan Santoso, A., Penerbit Buku Kedokteran EGC, Jakarta

Harborne, J. B., 1987, Metode Fitokimia, Penuntun Cara Modern Menganalisis Tumbuhan, $2^{\text {nd }}$ ed., a.b. Kosasih dan Iwang, Penerbit ITB, Bandung

Harborne, J. W., and Simmonds, N. W., 1964, Biochemistry of Phenolic Compounds, Academic Press, London.

Schubert, S. Y., Lansky, E. P., and Neeman, I., 1999, Antioxidant and Eicosanoid Enzyme Inhibition Properties of Pomegranate Seed Oil and Fermented Juice Flavonoids, Journal of Ethnopharmacology, 66 (1): 11-17

Sini, K. R., Sinha, B. N., Karpakavalli, M., and Sangeetha. P. T., 2011, Analgesic and Antipyretic activity of Cassia occidentalis Linn, Annals Biologic Research, 2 (1): 195-200

Tjandra, O., Rusliati, R., dan Zulhipri, 2011, Uji Aktifitas Antioksidan dan Profil Fitokimia Kulit Rambutan Rapiah (Nephelium lappaceum), Karya Ilmiah, UPT Penerbitan dan Percetakan UNS, Solo

You, K. M., Jong, H. G., and Kim, H. P., 1999, Inhibition of Cyclooxygenase / Lipooxygenase from Human Platelets by Polyhidroxylated / Methoxylated Flavonoids Isolated from Medicinal Plants, Arch Pharm Res, 22 (1): 18-24 
JURNAL KIMIA 11 (2), JULI 2017: 107-112

Zainol, Q., Hidayat, E. M., dan PeryogaS. U., 2014,Antipyretic Effect of Cinnamomum burmannii (Nees \& T.Nees) Blume Infusion in Feverinduced Rat Models, Althea Medical Journal, 1 (2): 81-85 